\title{
Rice Sheath Blight: A Review of Disease and Pathogen Management Approaches
}

Yellareddygari SKR*, Reddy MS, Kloepper JW, Lawrence KS and Fadamiro H

Department of Entomology \& Plant Pathology, Auburn University, Auburn, AL, USA

\begin{abstract}
Rice is an important food grain and is a staple food for majority of the world's population. To meet increasing global demand and consumption, rice productivity must be enhanced. However, biotic stresses such as diseases have impeded rice cultivation both in the tropics and subtropics. Of them, sheath blight is a major soil borne disease causing economic losses to rice cultivation. This article summarizes sheath blight (ShB) of rice, disease etiology and economics. Elaborative and updated accounts of various management options and their efficacy for ShB control are given. Specifically, the effects of popular cultural practices influencing ShB incidence, various chemical fungicides, and biological control individually and their combined effect on ShB are presented. The role of Plant Growth-Promoting Rhizobacteria (PGPR) and various genera of PGPR in ShB suppression are discussed. The present review also showed various aspects relating to ShB suppression by PGPR such as antagonism, competition for space and essential nutrients, and induction of systemic resistance. Integrated management of ShB involving all the compatible combinations is included in this review.
\end{abstract}

Keywords: Rice; Sheath blight; Fertilizers; Antagonism; Biological control

\section{Importance of Rice Crop}

The world's population is expected to surge from 6.1 billion in 2000 to 9.2 billion in 2050 [1]. A significant increase in predicted human population requires increasing crop yields to meet the requirements of the rising global demand for food. At current annual rate, the world population is expected to grow at $1.2 \%$ or approximately 77 million people per year [2]. Six countries, India, China, Pakistan, Bangladesh, Nigeria, and Indonesia, account for majority of the annual population growth. Of these, four countries, India, China, Pakistan, and Bangladesh, are major consumers of rice cereal. Regardless of major advances in agriculture science over the past 50 years, a significant number of the world's population suffer from hunger and undernourishment. Lack of balance between crop production and demographic food demand is due to existence of hunger and malnutrition $[3,4]$. With this population rise, it is expected that a corresponding food security problem will occur with the probability of losing agricultural land to industrialization and urbanization. Agriculture practices have incorporated greater part of world's available fertile farmland, which may limit further area expansion to low/non fertile land [5-7]. In addition to existing farmland problems, constrained farmland availability and identification of new plant diseases compound the challenges growers and scientists face globally to meet the nutritional requirements of the growing population.

Rice is a monocotyledonous annual grass, and belongs to the family Gramineae and the genus Oryza. Oryza includes 20 wild species and two cultivated species: Oryza sativa (grown throughout the world) and Oryza glaberrima (grown only in Africa) [8]. Globally, more than 3 billion people have rice as staple food, and it accounts for 50 to $80 \%$ of their daily calorie intake [9]. Over the next 20 years it is expected that demand for rice will grow by $2.5 \%$ per year [10]. Currently, China and India are ranked first and second in rice production according to Foreign Service Association of United States Department of Agriculture statistics [11]. Together they account for $51.4 \%$ of total world milled rice production.

Agriculture in the U.S. is diverse with the highest productivity when compared to other countries in terms of meeting its domestic food requirements and exporting a large amount of goods produced from a wide variety of crops [11]. Rice is no exception. Rice production in the U.S. is known to be diverse and includes all type of rice: short, medium, long grain and specialty rice [11]. Of the total estimate of world rice production of 450,200 thousand Metric tons (Mt), production in the U.S. accounts for up to $1.67 \%$ [11]. A significant part of the rice produced in the U.S. is exported in the international market, ranking the U.S. third among the leading global exporters of milled rice [11]. Each year in the U.S., 2.7 million acres of cultivation produce 19 billion pounds of rice, out of which approximately $50 \%$ is supplied to the domestic market (http://www.usarice.com/doclib/188/219/3674.PDF). Industrial and research advances have allowed the U.S. rice industry to flourish in a short time. In spite of successful adaptation of scientific developments and establishment of rice crop, pests and pathogens are inevitable and protective methods should be available to minimize the crop loss.

\section{Sheath Blight of Rice}

The world's huge rice agro-ecosystem, designed to feed the ever increasing human population, also provides a habitat for great number of pests and pathogens. Rice diseases can cause significant quality and yield losses and can be a threat to the U.S. rice export industry. Rice sheath blight (ShB), caused by Rhizoctonia solani Kuhn (Teleomorph: Thanatephorus cucumeris (Frank) Donk), is a destructive disease worldwide that causes significant yield loss and quality degradation $[12,13]$. Apart from rice, the pathogen also infects many other plant

*Corresponding author: Yellareddygari SKR, Department of Entomology \& Plant Pathology, Auburn University, Auburn, AL, USA, Tel: 5598249954; E-mail: shashikiranreddy.yel@ndsu.edu

Received: April 07, 2014; Accepted October 23, 2014; Published October 25 2014

Citation: Yellareddygari SKR, Reddy MS, Kloepper JW, Lawrence KS, Fadamiro H (2014) Rice Sheath Blight: A Review of Disease and Pathogen Management Approaches. J Plant Pathol Microb 5: 241. doi:10.4172/2157-7471.1000241

Copyright: () 2014 Yellareddygari SKR, et al. This is an open-access article distributed under the terms of the Creative Commons Attribution License, which permits unrestricted use, distribution, and reproduction in any medium, provided the original author and source are credited. 
species, including barley, lettuce, tomato, sorghum, and maize [14]. A significant amount of achievable rice production is safeguarded from $R$. solani by using protection strategies. In their absence, rice ShB disease causes $10-30 \%$ yield loss [15] and may reach up to 50\% during prevalent years [16]. In China only, about 15 to 20 million ha of rice growing area is affected, causing losses of 6 million tons of grains per year [15]. Planting ShB susceptible rice varieties in the U.S. resulted in yield losses of about $50 \%$ in trial plots $[15,17]$. In Arkansas, ShB was found present in $50-66 \%$ of rice fields, causing $5-15 \%$ yield losses in $2001[18,19]$.

Rhizoctonia solani is a universal soil saprotrophic and facultative plant parasite [20,21]. The pathogen has limited movement due to lack of spores and survives in unfavorable conditions by forming sclerotia or dormant mycelia $[21,22]$. Sclerotia in soil can survive for 2 years, and are spread during field preparation and flooding the field for irrigation $[23,24]$. During permanent flooding the sclerotia may float and move within the field or to bordering fields through continuous flood irrigation. Sclerotia or hyphae attach to the plant, infecting and causing ShB disease, and the pathogen spreads under conditions favorable to disease development. Initial symptoms occur on leaf sheaths near the water line as water-soaked lesions. Secondary infections are caused by hyphae growing upward towards uninfected plant parts, producing additional lesions and sclerotia on leaf sheaths to complete the disease cycle $[23,24]$.

The disease develop quickly during flowering when the rice canopy is most dense, forming a microclimate favorable to pathogen growth and spread [24]. R. solani can infect seed to fully mature plant, causing moderate to significant yield losses depending on the plant part affected. Visible plant disease symptoms include formation of lesions, plant lodging, and presence of empty grains. Large lesions formed on infected sheaths of lower rice leaves may lead to softness of the stem thereby initiating stem lodging [25]. Lodging alters the normal rice canopy design, affecting photosynthetic ability and total biomass production $[25,26]$. ShB presence during panicle initiation or flowering causes a reduction of total seed weight due to a lower percentage of filled spikelets and results in significant yield losses [13]. During rice sheath blight epidemics, severe lodging may occur, which obstructs the transportation of water, nutrients, and carbohydrate assimilates through the xylem and phloem channels, affecting grain filling [25]. Disease spread and intensity is dependent on the amount of infectious inoculum present in planting material and residues of previous crop remaining in the field or in the top soil where rice is grown. Other impact factors for ShB disease severity are rice development stage at infection, ecological surroundings, cultivar resistance, and cultural and seasonal crop practices $[27,28]$.

The use of high rates of $\mathrm{N}$ fertilizer, double cropping, high plant densities, and early maturing, dwarf build, high tillering and susceptible varieties have been shown to enhance $\mathrm{ShB}$ severity in most of the world's rice growing areas $[12,13]$. In addition, plant morphological traits of rice cultivars are known to enhance ShB severity. Studies conducted on plant morphological characters and their relation with ShB development confirmed that plant height alters microclimate and light transmission inside the dense canopy, thereby facilitating disease development $[29,30]$.

It is common for growers to apply rates of $\mathrm{N}$ higher than those recommended for rice. This results in lush green vegetative growth conducive to pathogen spread. Rice produces increased numbers of tillers when high $\mathrm{N}$ doses are applied, which increases its susceptibility to pathogens and insects. High $\mathrm{N}$ rates facilitate the $\mathrm{ShB}$ disease development and spread by increasing tiller density and moisture retention inside the rice canopy [30,31]. Therefore, $\mathrm{N}$ fertilizer management should be adopted for rice crop, which would increase nitrogen use efficiency during the growing season and diminish ShB disease concerns.

\section{Sheath Blight Disease Management}

Rice plants respond to various stresses in their surroundings by comprising attack by pests and pathogens like bacteria, fungi, virus, and nematodes. Plant defense responses correspond to the type of attacking external agent. The plant capacity to respond to an infection is determined by both the host and pathogen genetic traits [32]. To protect against pathogen infection plants have conferred various defense mechanisms such as, gene-for-gene interactions, and signal transduction networks that require jasmonic acid and ethylene $[33,34]$. However, a virulent pathogen overcomes a plant's defense mechanism by evading the effects of activated defenses, avoiding triggering plant defenses, or suppressing the plant's resistance reactions [35]. The virulent pathogen that escapes from the plant's natural defense will cause disease. A range of $\mathrm{ShB}$ disease control measures have been reported in the literature.

\section{Cultural control}

One approach to sustainable disease management without the use of chemicals is to develop disease-resistant cultivars. Benefits from disease-resistant cultivars include reduced disease incidence and increased grain and milling yields [36]. To date, resistance breeding efforts against ShB has been only moderately successful, mainly due to a lack of source for resistance in cultivated rice or in wild related species $[24,37]$. Nevertheless, rice cultivars ranging from susceptible to moderately resistant to $\mathrm{ShB}$ are available for cultivation. The development of new resistant cultivars was hampered through direct screening of germplasm because the fungal pathogen $R$. solani is plurivorous and semisaprobiotic [38]. Using molecular plant breeding programs, researchers manipulate the identified pathogen resistant genes to develop commercially resistant cultivar. So far, these attempts were ineffective and this may be attributed to the resistance being controlled by multiple genes or quantitative trait loci (QTLs) [39]. Although ShB resistance QTLs have been identified in 12 rice chromosomes, only few were mapped and most did not show any effect [40]. Current lack of effective resistant cultivars has led growers to rely increasingly on chemical fungicides.

\section{Chemical control}

Fungicides are widely used for combating rice ShB infection. Both systemic and non-systemic fungicides are available. Since systemic fungicide introduction in the 1960s, they generally provide better disease management than non-systemic products [32]. New products have been added to the market through fungicide research by agrichemical companies. Current fungicide research is mainly aimed at identification of suitable and novel target sites [32]. Several fungicides having novel modes and sites of action are available to growers for suppression o R. solani. At present, systemic fungicides belonging to the strobilurin group are used extensively to combat rice $\mathrm{ShB}$ pathogen.

Within the strobilurins group, azoxystrobin fungicide is widely used as it works effectively against ShB pathogen infestation [41] The fungicide is a derivative of $\beta$-methoxyacrylate and was the first registered fungicide from this class of chemistry $[42,43]$. It is sold as Quadris 2.08 SC (Syngenta, Raleigh, NC). Azoxystrobin is considered one of the best fungicides in the U.S. for sheath blight control [43]. The mode of action of azoxystrobin is to inhibit electron transport and kill 
the fungal pathogen $[42,43]$. Use of fungicide rate and composition is based on intensity of disease and the type of cultivars (susceptible/ medium susceptible/ moderately resistant) used. Benefits from fungicide control include lower disease incidence, likely reduction of inoculum, and improved grain and milling yields $[44,45]$.

Research findings suggest the chance of a pathogen developing resistance to a particular chemical increases with regular use over a period of time $[14,46]$. The alternatives are to develop a new line of a chemical (fungicide) class that has no cross resistance to the chemical to which the pathogen developed resistance originally or to develop other preventative strategies free of chemicals. Manufacturing and releasing a new line of pesticide into the market are time consuming, expensive, and involve the risk of failure. Recently it was reported that only few chemicals have been introduced thereby creating shortage of pathogen control tools for most specialty crops [47]. One reason for this may be due to stringent pesticide regulations adopted by policy makers to prevent the use of chemicals considered too dangerous to human health and the environment.

Chemical control, though effective in managing disease, often has a significant impact on humans and the natural environment through the pollution of soils, above and below ground water resources, and the entire food supply chain. Human health and environmental protection regulations are strict. A major goal in developing a new fungicide is to ensure a good balance between potency and safety [48]. A fungicide that is effective against disease but fails to meet the area/topic regulations standardized by the representative group/organization may be banned completely from use. Furthermore, new pesticide should undergo constant reassessment, re-registration and changing guidelines of application techniques and residue levels [48].

A product that clears all regulations is patented and sold in the market. Patent time varies with the country of application. The success of the product is not guaranteed, as it may have competition from rival products, and it may develop pathogen resistance [32]. Each time a pathogen develops resistance to a pesticide in use, a replacement for the existing pesticide should be readily available. Due to the uncertainty of pathogen behavior to chemicals, it is necessary to develop nonchemical control methods.

\section{Biological control using PGPR}

Antagonism between organisms is common in the ecosystem and is most prevalent among soil microorganisms. Natural interference between beneficial soil microorganisms and plant pathogens results in zone of buffer, thereby inhibiting or reducing disease development [49]. Various microbial defense mechanisms may work independently or together, depending on the rhizosphere or phyllosphere characteristics. Managing soil-abundant beneficial microbes for the improvement of plant root and shoot growth and plant health is an exciting field. Microbial interactions in the rhizosphere influence plant health and soil fertility [50]. Advancements in biological control have led to identification and development of antagonistic bacteria with plant and root growth stimulating ability.

Rhizosphere-isolated, free living soil bacteria with proven plant beneficial properties are known as plant growth- promoting rhizobacteria (PGPR) [51]. Besides, PGPR role in increasing plant or root growth, they directly influence increased $\mathrm{N}$ uptake, phosphate solubilization, phytohormone synthesis, and production of iron chelating siderophores $[25,52,53]$. Some PGPR are used commercially to enhance plant growth and health. Seed treatment of rice with PGPR resulted in increased root and shoot length of seedlings [54].

PGPR are also known for biological control of various soilinhabiting bacteria. PGPR are used in ecofriendly products. They are naturally available in the environment and provide resistance against a broad spectrum of pathogens [55]. The microbial populations in rhizosphere can be influenced by soil characteristics, agronomic practices, and plant type [55]. Inconsistent results of PGPR applications between the laboratory, greenhouse, and field studies can be due to changes in climate or soil [56]. An improved understanding of microbial population dynamics is needed before amending the farming practices to enhance plant growth and yield.

PGPR induce pathogen suppression by different modes of action such as antagonism, competition for space and essential nutrients, and initiation of systemic resistance (ISR) [25]. The concept of activating plants defense pathways to control pathogen infection is appealing, though difficult to implement effectively. Induced resistance occurs when a plant, once appropriately stimulated, exhibits an enhanced resistance upon challenge inoculation with the pathogen [57]. This type of resistance is mostly systemic in nature, spreading from point of infection to other distant plant parts [57]. PGPR might be more effective when combined with other ShB disease control methods through an integrated approach.

\section{Moving forward with integrated disease management}

In many countries rice is grown in the same field year after year, making it more susceptible to soilborne pathogens. Over time, pathogen inoculum accumulates in crop soil or surrounding fields and can cause epiphytotic disease. Over use or over dependence on chemical control or any other single control method is not sufficient to manage rice $\mathrm{ShB}$. A systemic control approach uniting all ShB disease management options may produce better pathogen management. Integrated disease management (IDM) of rice ShB is broad-based, ecological plant pathogen control approach, combining all the available disease control methods with each method compensating the deficiencies of others [54]. IDM is recommended year round to monitor major crop programs. Regardless of any complete $\mathrm{ShB}$ resistance, growers may manage the disease using IDM. Forthcoming, educating farmers and disseminating information about effective and environmentallysound IDM mitigate rice ShB pathogen damage while accomplishing sustainable farming. Although challenging, future research should also focus on identifying and developing cost effective complete resistance lines through conventional or molecular breeding.

\section{References}

1. UN (United Nations) World Population Prospects (2005) The 2004 Revision Highlights. Population Division, Department of Economic and Social Affairs. United Nations, NY.

2. Fernando PC (2006) Agriculture, pesticides, food security and food safety Environmental Science \& Policy 9: 685-692.

3. FAO (Food and Agriculture Organization of the United Nations) (2002) Reducing poverty and hunger: The critical role of financing for food, agriculture and rural development.

4. Skamnioti P, Gurr SJ (2009) Against the grain: safeguarding rice from rice blast disease. Trends Biotechnol 27: 141-150.

5. Young $A(1999)$ Is there really spare land? A critique of estimates of available cultivable land in developing countries. Environ. Dev. Sustainability 1: 3-18.

6. Cassman KG (1999) Ecological intensification of cereal production systems: yield potential, soil quality, and precision agriculture. Proc Natl Acad Sci U S A 96: 5952-5959. 
Citation: Yellareddygari SKR, Reddy MS, Kloepper JW, Lawrence KS, Fadamiro H (2014) Rice Sheath Blight: A Review of Disease and Pathogen Management Approaches. J Plant Pathol Microb 5: 241. doi:10.4172/2157-7471.1000241

7. Tilman D, Cassman KG, Matson PA, Naylor R, Polasky S (2002) Agricultural sustainability and intensive production practices. Nature 418: 671-677.

8. Pareja L, Fernández-Alba AR, Cesio V, Heinzen H (2011) Analytical methods for pesticide residues in rice. TrAC Trends in Analytical Chemistry 30: 270-291.

9. Delseny M, Salses J, Cooke R, Sallaud C, Regad F, et al. (2001) Rice genomics: Present and future. Plant Physiology and Biochemistry 39:323-334.

10. Hobbs PR (2001) Tillage and crop establishment in South Asian rice-wheat systems: present and future options. J Crop Prod 4: 1-23

11. FSA/USDA, Foreign Service Association of United States Department of Agriculture Office of Global Analysis (2011)

12. Lee FN, Rush MC (1983) Rice sheath blight: a major rice disease. Plant Dis 67: 829-832

13. Nagarajkumar $M$, Bhaskaran $R$, Velazhahan $R$ (2004) Involvement of secondary metabolites and extracellular lytic enzymes produced by Pseudomonas fluorescens in inhibition of Rhizoctonia solani, the rice sheath blight pathogen. Microbiol Res 159: 73-81.

14. Zhang CQ, Liu YH, Ma XY, Feng Z, Ma ZH (2009) Characterization of sensitivity of Rhizoctonia solani, causing rice sheath blight to mepronil and boscalid. Crop Protection 28: 381-386.

15. Xie XW, Xu MR, Zang JP, Sun Y, Zhu LH, et al. (2008) Genetic background and environmental effects on QTLs for sheath blight resistance revealed by reciprocal introgression lines in rice. Acta Agronomica Sinica 34:1885-1893.

16. Meng QZ, Liu ZH, Wang HY, Zhang SS, Wei SH (2001) Research progress in rice sheath blight. (in Chinese with English abstract) J. Shenyang Agric Univ 32:376-381

17. Prasad B, Eizenga GC (2008) Rice sheath blight disease resistance identified in Oryza spp. Accessions. Plant Dis 92: 1503-1509.

18. Annou MM, Wailes EJ, Thomsen MR (2005) A dynamic decision model of technology adoption under uncertainty: case of herbicide-resistant rice. J. of Agricultural and Applied Economics 37: 161-172

19. Tan WZ, Zhang W, Ou ZQ, Li CW, Zhou GJ, et al. (2007) Analyses of the temporal development and yield losses due to sheath bight of rice (Rhizoctonia solani AG1.1a). Agricultural Sciences in China 6: 1074-1081.

20. Ogoshi A (1996) Introduction of the genus Rhizoctonia: Taxonomy, Molecular Biology, Ecology, Pathology and Disease Control. Kluwer Academic Publishers, Dordrecht, NL.

21. Anees M, Edel-Hermann V, Steinberg C (2010) Buildup of patches caused by Rhizoctonia solani. Soil Biology and Biochemistry 42:1661-1672.

22. Sumner DR (1996) Sclerotia formation by Rhizoctonia species and their survival: Taxonomy, Molecular Biology, Ecology, Pathology and Disease Control. Kluwer Academic Publishers, Dordrecht, NL.

23. Webster RK, Gunnell PS (1992) Compendium of Rice Diseases. American Phytopathological Society, St. Paul, MN, USA.

24. Brooks SA (2007) Sensitivity to a Phytotoxin from Rhizoctonia solani Correlates with Sheath Blight Susceptibility in Rice. Phytopathology 97: 1207-1212.

25. Wu W, Huang J, Cui K, Nie L, Wang Q, et al. (2012) Sheath blight reduces stem breaking resistance and increases lodging susceptibility of rice plants. Field Crops Research 128: 101-108.

26. Hitaka H (1969) Studies on the lodging of rice plants. Jpn. Agric. Res. Quart 4:1-6.

27. Gangopadhyay S, Chakrabarti NK (1982) Sheath blight of rice. Rev. Plant Pathol. 61:451-460.

28. Groth DE, Rush MC, Hollier CA (1992) Prediction of rice sheath blight severity and yield loss based on early season infection. La. Agric 35:20-23.

29. Han YP, Xing Y, Gu S, Chen Z, Pan X, et al. (2003) Effect of morphological traits on sheath blight resistance in rice. Acta Botanica Sinica 45: 825-831.

30. Tang Q, Peng S, Buresh RJ, Zou Y, Castilla NP, et al. (2007) Rice varietal difference in sheath blight development and its association with yield loss at different levels of $\mathrm{N}$ fertilization. Field Crops Research 102: 219-227.

31. Savary S, Castilla NP, Elazegui FA, McLaren CG, Ynalvez MA, et al. (1995) Direct and indirect effects of nitrogen supply and disease source structure on rice sheath blight spread. Phytopathology 85: 959-1011.

32. Gullino ML, Leroux P, Smith CM (2000) Uses and challenges of nove compounds for plant disease control. Crop Protection 19: 1-11.
33. Glazebrook J (2001) Genes controlling expression of defense responses in Arabidopsis--2001 status. Curr Opin Plant Biol 4: 301-308.

34. Ramonell KM, Somerville S (2002) The genomics parade of defense responses: to infinity and beyond. Curr Opin Plant Biol 5: 291-294.

35. van Loon LC, Bakker PA, Pieterse CM (1998) Systemic resistance induced by rhizosphere bacteria. Annu Rev Phytopathol 36: 453-483.

36. Groth DE, Rus, MC, Giesler GG, Hollier CA (1993) Foliar fungicides for use in the management of rice diseases. La Agric Exp Stn Bull No. 840.

37. Pan XB, Rush MC, Sha XY, Xie QJ, Linscombe SD, et al. (1999) Major gene, nonallelic sheath blight resistance from the rice cultivars Jasmine 85 and Teqing. Crop Sci 39: 338- 346.

38. Zuo SM, Wang ZB, Chen XJ, Gu F, Zhang YF.et al. 2009. Evaluation of resistance of a novel rice line YSBR1 to sheath blight. Acta Agronomica Sinica 35:608-614.

39. Pinson SRM, Capdevielle FM, Oard JH (2005) Confirming QTLs and finding additional loci conditioning sheath blight resistance in rice using recombinant inbred lines. Crop Sci 45: 503-510.

40. Zeng YX, Ji ZJ, Ma LY, Li XM, Yang CD (2011) Advances in mapping loci conferring resistance to rice sheath blight and mining Rhizoctonia solan resistant resources. Rice Sci 18: 56-66.

41. Groth DE, Bond JA (2006) Initiation of rice sheath blight epidemics and effect of application timing of azoxystrobin on disease incidence, severity, yield, and milling quality. Plant Disease 90: 1073-1076.

42. Anonymous (1996) New fungicide for disease control on fruit and nut crops Zeneca Incorp. Tech, Information Bulletin, Wilmington, DE.

43. Grichar WJ, Jaks AJ, Besler BA (2004) Response of peanuts (Arachis hypogaea) to weather-based fungicide advisory sprays. Crop Protection 24 349-354

44. Groth DE (2008) Effects of cultivar resistance and single fungicide application on rice sheath blight, yield, and quality. Crop Protection 27: 1125-1130.

45. Groth DE (1996) Two new fungicides to control rice diseases. La. Agric 39 31-33.

46. Brent K J, Hollomon DW (1998) Fungicide Resistance: the Assessment of Risk. FRAC Monograph, 2. CropLife International, Brussels, Belgium.

47. Zilberman D, Millock K (1997) Financial incentives and pesticide use. Food Policy 22: 133-144

48. Knight SC, Anthony VM, Brady AM, Greenland AJ, Heaney SP, et al. (1997) Rationale and perspectives on the development of fungicides. Annu Rev Phytopathol 35: 349-372.

49. Köhl J, Postma J, Nicot P, Ruocco M, Blum B (2011) Stepwise screening of microorganisms for commercial use in biological control of plant-pathogenic fungi and bacteria. Biological Control 57: 1-12.

50. Jeffries P, Gianinazzi S, Perotto S, Turnau K, Barea JM (2003) The contribution of arbuscular mycorrhizal fungi in sustainable maintenance of plant health and soil fertility. Biol Fertil Soils 37: 1-16.

51. Kloepper JW, Schroth MN (1978) Plant growth promoting rhizobacteria on radish.: Proceedings of the Fourth Conference Plant Pathogenic Bacteria INRA, Angers, France.

52. Lalande R, Bissonnette N, Coutlee D, Autoun H (1989) Identification of rhizobacteria from maize and determination of their plant-growth promoting potential. Plant and Soil 115: 7-11.

53. Bowen GD, Rovira AD (1999) The rhizosphere and its management to improve plant growth. Advances in Agronomy 66:1-102.

54. Kumar KVK, Reddy MS, Kloepper JW, Lawrence KS, Groth DE, et al. (2009) Sheath blight disease of rice (Oryza sativa L.) -An overview. Biosciences Biotechnology Research Asia 6: 465-480.

55. Radjacommare R, Kandan A, Nandakumar R, Samiyappan R (2004) Association of the hydrolytic enzyme chitinase against Rhizoctonia solani in rhizobacteria-treated rice plants. Journal of Phytopathology 152: 365-370.

56. Lucy M, Reed E, Glick BR (2004) Applications of free living plant growthpromoting rhizobacteria. Antonie Van Leeuwenhoek 86: 1-25.

57. Dutta S, Mishra AK, Dileep Kumar BS (2008) Induction of systemic resistance against fusarial wilt in pigeon pea through interaction of plant growth promoting rhizobacteria and rhizobia. Soil Biology and Biochemistry 40: 452-461. 